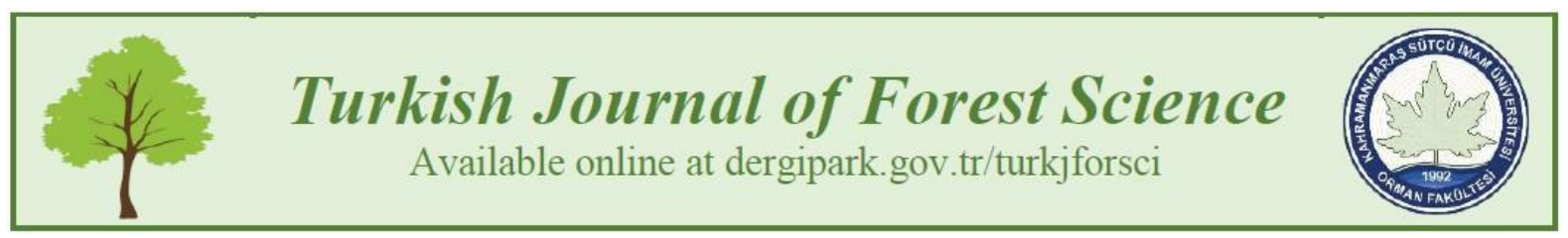

\title{
DETERMINATION OF THE DISTORTIONS OCCURRING IN THE ENTRANCE PATH OF THE NEMRUT CALDERA NATURAL MONUMENT AND THE PROPOSAL LANDSCAPE STUDIES
}

\author{
Sevket ALP ${ }^{1}$, Okan YELER $^{2 *}$, Basri MUTLU ${ }^{3}$ \\ ${ }^{1}$ Department of Landscape Architecture, Van Yuzuncu Yil University, Van \\ ${ }^{2}$ Muradiye Vocational School, Van Yuzuncu Yil University, Van \\ ${ }^{3}$ Hakkari Forestry Operation Directorate, Hakkari \\ ${ }^{*}$ Corresponding author: okanyeler@yyu.edu.tr
}

Sevket ALP: https://orcid.org/0000-0002-9552-4848

Okan YELER: https://orcid.org/0000-0002-0405-4829

Basri MUTLU: https://orcid.org/0000-0001-7127-7590

Please cite this article as: Alp, S., Yeler, O. and Mutlu, B. (2019). Determination of the distortions occurring in the entrance path of the nemrut caldera natural monument and the proposal landscape studies, Turkish Journal of Forest Science, 3(2), 149-158.

\author{
ARTICLE INFO \\ Research Article \\ Received 31 July 2019 \\ Received in revised form 16 September 2019 \\ Accepted 17 September 2019 \\ Published online 27 October 2019
}

\begin{abstract}
Nemrut Stratovolcano is located on the west coast of Lake Van in Eastern Anatolia. Nemrut Stratovolcano has completed its geological evolution in three main phases: Pre-Caldera Phase, Post-Caldera Phase and Late Phase. In this process, many changes were observed in the area where Caldera is located. It is observed that there have been shifts on the last pyramidal units of Caldera, which is located on the road between Tatvan and Nemrut Caldera. These units, called base spreading products, are located on rhyolitic obsidian and trachies. The unit covers an area of $22 \mathrm{~km} 2$ in the eastern parts of the Nemrut Caldera and has an average thickness of $15 \mathrm{~m}$. In this study, the investigations in the area revealed that the pyroclastics were free of cohesion, and the flows and drifts arising from the surface waters. Depending on the thickness of the mass, these flows continue along the surface of the slope towards the deep and threaten the existing road. In this context, it is aimed to determine the deteriorations in the transportation road and to contribute to the fact that this area, which is based on the historical stages, can be a sustainable and permanent natural monument with some landscaping works.
\end{abstract}

Keywords: Nemrut Caldera, Tatvan, Natural Monument, Proposal Landscape Studies 


\section{NEMRUT KALDERASI TABIAT ANITI'NIN GIRISS YOLUNDA MEYDANA GELEN BOZULMALARIN TESPITI VE ÖNERI PEYZAJ ÇALIŞMALARI}

\section{ESER BİLGİSi}

Araştırma Makalesi

Geliş 31 Temmuz 2019

Düzeltmelerin gelişi 16 Eylül 2019

Kabul 17 Eylül 2019

Yayımlanma 27 Ekim 2019

ÖZET: Nemrut Stratovolkanı, Doğu Anadolu bölgesinde Van Gölü’nün batı kıyısında yer almaktadır. Nemrut Stratovolkanı jeolojik evrimini Kaldera Öncesi Evre, Kaldera Sonras1 Evre ve Geç Evre olmak üzere üç ana evrede tamamlamıştır. Bu süreçte Kaldera'nın bulunduğu alanda birçok değişiklik gözlenmiştir. Tatvan ile Nemrut Kalderası yolu üzerinde yer alan Kaldera'nın son pirokratik birimleri üzerinde kaymaların meydana geldiği gözlenmektedir. Taban yayılımı ürünleri olarak isimlendirilen bu birimler riyolitik obsidiyen ve trakitlerin üzerine yerleşmiştir. Nemrut Kalderasının doğu kısımlarında yaklaşık 22 km2'lik bir alan kaplayan birim ortalama $15 \mathrm{~m}$ kalınlığındadır. Tutturulmamış ve gevşek yapıda olan birim kolay aşınabilen, devrilebilen ve kayabilen özellikler göstermektedir $\mathrm{Bu}$ çalışmada, alanda yapılan incelemelerde piroklastiklerin kohezyonsuz olmalarından ve yüzey sularından kaynaklanan akmalar ve kaymalar tespit edilmiştir. Bu akmalar kütlenin kalınlığına bağlı olarak derinlere doğru şev yüzeyi boyunca devam etmekte ve mevcut yolu tehdit etmektedir. Bu kapsamda ulaşım yolunda meydana gelen bozulmalar tespit edilerek öneri bazı peyzaj çalışmaları ile tarihi evrelere dayanan bu alanın sürdürülebilir ve kalıcı bir tabiat anıtı olabilmesine katkı sağlanması amaçlanmıştır.

Anahtar kelimeler: Nemrut Kalderası, Tatvan, Tabiat anıtı, Peyzaj öneri çalışmaları

\section{INTRODUCTION}

Ecological, economic, historical and cultural tourism areas with special importance, such as natural monuments, are generally touristic places surrounded by rural and urban people around them. Therefore, ecological and economic contributions of such areas benefit the people of the region, while its careful conservation contributes to the sustainability of many biological diversity. Economic benefits for social development are also being created through eco-tourism-like activities in the fields that are close to the city center.

In order for these types of fields to be sustainable and be transformed into the economy, the environmental regulation and the improvement of the visual quality of the surrounding landscape needs to be done by expert persons and institutions. While landscaping works are carried out, the current status of the terrain in the project areas, the structure of soil, climate conditions and the type selection depending on the appropriate vegetation cover are taken into consideration. Planting areas can consist of very inclined slopes. However, detailed and delicate forestation works are needed in the slope areas occurring as a result of the tear and rift in nature, especially in rural landscape areas with highways applications (Akman, 1990).

Other areas that protected, or should be protected, such as nature areas, have been tried to be secured by some laws to maintain sustainability. However, planning should be carried out in 
accordance with the criteria and sensitivities that emerge in practice, the future-related status analysis should be made, and especially in order to maintain ecological functions, identification and evaluation should be revealed (Yeler, 2017).

In this study, some state assessments and landscape arrangements were proposed for Nemrut Caldera nature monument, which is considered to be a center of attraction for winter tourism and which is admitted to be an appropriate potential area for contributing to the region's economy. Through in situ studies conducted at the Nemrut Caldera nature monument, it was found that pyroclastic rocks were not cohesive, and flows and slippages caused by surface waters had been formed. These flows continue along the slope surface towards the depths depending on the thickness of the mass and threaten the current path. In this context, this area was intended to be a sustainable and permanent nature monument by determining the distortions that occur on the road of transportation.

\section{Study area}

Nemrut Stratovolcano is located on the west coast of Lake Van in Eastern Anatolia. The stratovolcano on the borders of the province of Bitlis is limited by the Van Lake coastline in the east, the Mus plain in the west, the Bitlis province in the south, and the Nazik Lake in the north (Figure 1). The activity of the volcano began approximately 1 million years ago and continued until the pre-historical periods. The highest point of the volcano is $2935 \mathrm{~m}$, having a caldera with a diameter of $8.5 \mathrm{~km}$ in the east-west direction, and $7 \mathrm{~km}$ in the north-south direction. Nemrut stratovolcano has completed its geological evolution in three major stages as a pre-caldera stage, post-caldera stage and late stage. In this process, many changes have occurred in the area of the caldera. It is observed that the slippages have occurred on the last pyrocratic units of the caldera, which are located on the road of Tatvan and Nemrut caldera. These units, known as base dispersion products, are located on rhyolitic obsidians and trachytes. The unit occupying an area of approximately $22 \mathrm{~km} 2$ in the eastern parts of Nemrut Caldera has an average thickness of $15 \mathrm{~m}$. The uncoated and loose structure of the unit can easily erode, fall or slide.

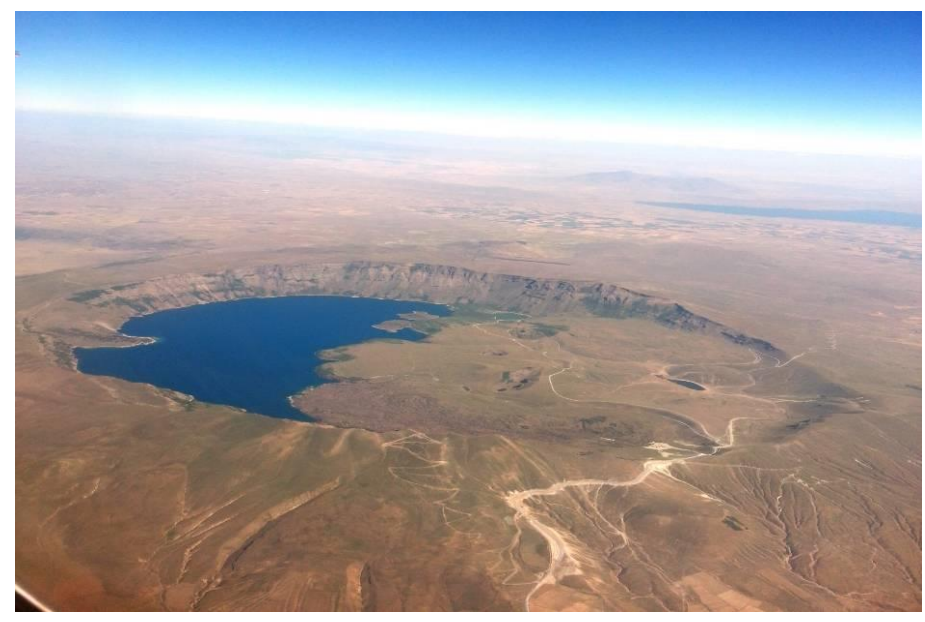

Figure 1: Aerial View Of The Study Area In Nemrut Caldera Natural Monument (2019)

\section{Climate structure and vegetation}


The climate is warm and temperate in the region of Tatvan district of Bitlis Province. The winter months are much rainier than the summer months. According to the Köppen-Geiger climate classification, its climate class can be called CSB (warm-dry climate in winter and summer) (Anonymous, 2018). According to Akman (1990), the region is under the influence of the low-rainy Mediterranean climate.

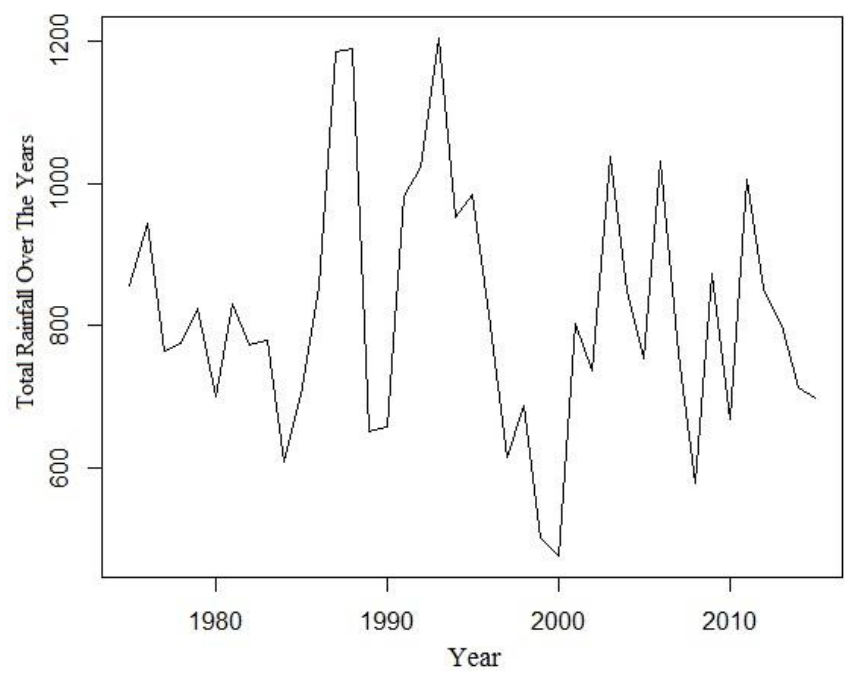

Figure 2: Total Rainfall Chart Of The Study Area By The Years (Anonymous, 2018).

The average annual temperature of Tatvan is $9.0^{\circ} \mathrm{C}$, and the average annual rainfall is 844 $\mathrm{mm}$. The driest month is July, with $6 \mathrm{~mm}$ of rainfall. The most precipitation falls are in April, with an average of $124 \mathrm{~mm}$ of precipitation (Figure 2). In the region, July is the hottest month of the year with a temperature of $21.3{ }^{\circ} \mathrm{C}$. The average temperature in January is $-2.5^{\circ} \mathrm{C}$, being the lowest average of the year. In the region, there are an absolute frost for three months and a likelihood of frost for five months, but also a moderate dry period until midJune to early October (Anonymous, 2018).

The region is located in the Iran-Turan phytogeographical region. For this reason, steppe fields, which have the typical vegetation of Iran-Turan phytogeographical region, is dominant. Apart from the steppe fields, plants belonging to habitats such as Rocky, Meadow, Creek edge spread (Tatl1, 1982). Vegetation development in the area begins in late March and early April at the foot of moist rocky areas where snow melts.

\section{Material}

\section{MATERIAL AND METHODS}

On-site investigations at the Nemrut Caldera Natural Monument revealed that the pyroclastics were cohesion-free and that there were runoffs and slippages from surface waters. In this context, it is necessary to know the existing landscape elements in the field, especially plant materials, in order to detect the disturbances that occur on the transportation road.

When the plant material in the area is examined, there is no forest formation in the research area (Figure 3). In Nemrut caldera, there are trees, shrubs and bush species that have been intensified around two lakes. Predominantly seen trees in the region are Betula Paddy Roth (huş), Populus tremula L. (quaking aspen), Juniperus communis L. subsp. Nana Syme (dwarf juniper), as well as, Acer platanoids (sycamore), Sorbus L. (rowan tree), Frangula llnus (alder 
dogwood), Cotoneaster horizontalis (rock cotoneaster), Cerasus Mahaleb (rock cherry), Prunus Domestica (Plum), Quercus L. (oak species) and Salix aegyptiaca L. (musk willow).

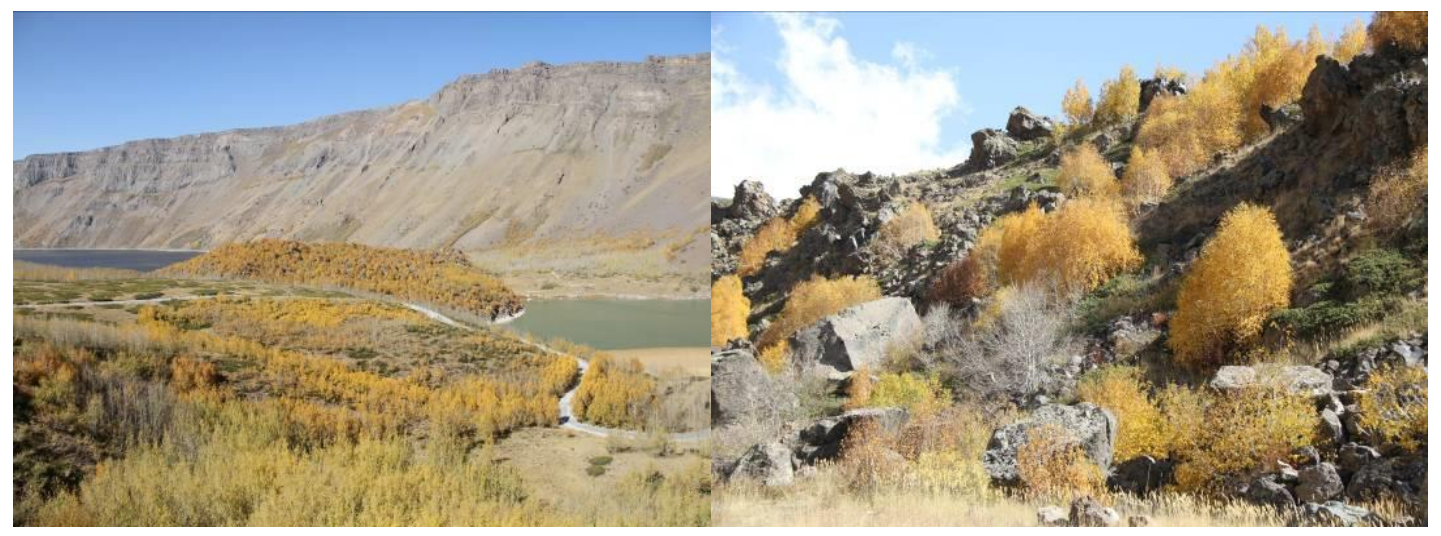

Figure 3. Image Of Existing Plants In The Workplace (2018)

Steppe type plants spread in a wide area across the caldera. There are several species mainly Astragalus membranaceus (tragacanth), including Acantholimon armenum (prickly thrift), Rumeks acetosella (sheep sorrel), Thymus ssp. (thyme), Alyssum pateri (aster linosyris), Festuca ovina (blue fescue), Salvia tomentosa (garden sage), Ranunculus asiaticus L.( wedding flower), Silene arguta (thyrsus), Trifolium arvense (trefoil), Pimpinella kotschyana (aniseed), Artemisia fragans (sagebrush), Fritallaria imperialis (tulip), Colchicum autumnale meadow saffron), Iris sp. (freesia), Orchis sp. (salep), Dactylorhıza sp (dactylorhiza urvilleana), Dianthus sp. (clove), Helichrysum sp. (amaranthus), Gundelia sp. (thistle), Centaurea sp. (cornflower) and endemically Ranunculus crateris Davis. (crater buttercup) (Tatl1, 1982; Özçelik, 2016).

\section{Methods}

Very steep cuts and slopes always show the risk of slipping during rainy months. Retaining walls are usually made of concrete to prevent slippage. But generally the walls cannot completely prevent erosion. In landscaping areas, trees, shrubs and grass species (or ground cover plants) with deep roots are used as a method of preventing collapse and erosion. Such plants absorb the water in the soil and dry it quickly, the roots scattered in the soil prevent the soil from breaking and slipping. The amount of slip in a planted area is 12 times less than the amount of slip in a bare area next to it. In addition to esthetic contributions to plants, some ugly images have features such as masking or the emergence of beautiful images. These functions of plants in landscape design are tried to be utilized with maximum use.

Largest method of the research is to determine the current situation using the data we have. The slippages on Tatvan Nemrut caldera road occur on the last pyroclastic units taken place after the formation of Nemrut Stratovolcano Caldera. These units, known as base dispersion products, are located on rhyolitic obsidians and trachytes. The unit occupying an area of approximately $22 \mathrm{~km}^{2}$ in the eastern parts of Nemrut Caldera has an average thickness of 15 $\mathrm{m}$. The unit consists of plentiful pumice and volcanic ash. The uncoated and loose structure of the unit can easily erode, fall or slide (Alp et al, 2017).

Due to the fact that pyroclastic rocks were not cohesive, the flows and slippages caused by surface waters were observed through the in situ investigation (Figure 4). These flows 
continue along the slope surface towards the depths depending on the thickness of the mass and threaten the current path. The wedge surface formed in deeper was not observable.

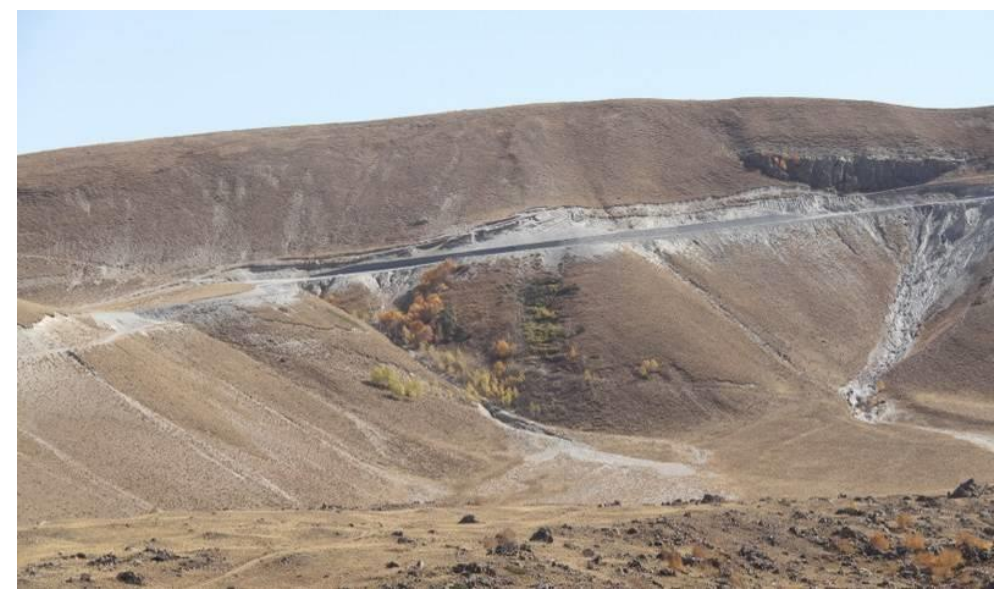

Figure 4. The View Of The New Road In Nemrut Caldera Nature Monument From The Direction Of Tatvan (2017)

\section{RESULTS}

Factors affecting erosion in the region are especially soil structure, climate, animal grazing, topographical structure, and human activities. The region is located in the zone of the Mediterranean climate with low rainfall; And with the effect of elevation and continentality, the summer months are semi-arid and low-rainy. Therefore, after the destruction of vegetation, it would be difficult to be regenerated. The vegetation in the region loses its soil with erosion following the destruction of vegetation, and as a result of this, anthropogenic drought occurs.

While designing the highway at the entrance of the Nemrut caldera, it was observed that the stabilization of the existing slopes was not made. These stabilization studies are one of the important issues that should take place in the first phase of the project. The applications of the road making work promote the formation of new slopes and current flows of the slopes. After all, the opened road leads to damage to the caldera (Figure 5) 


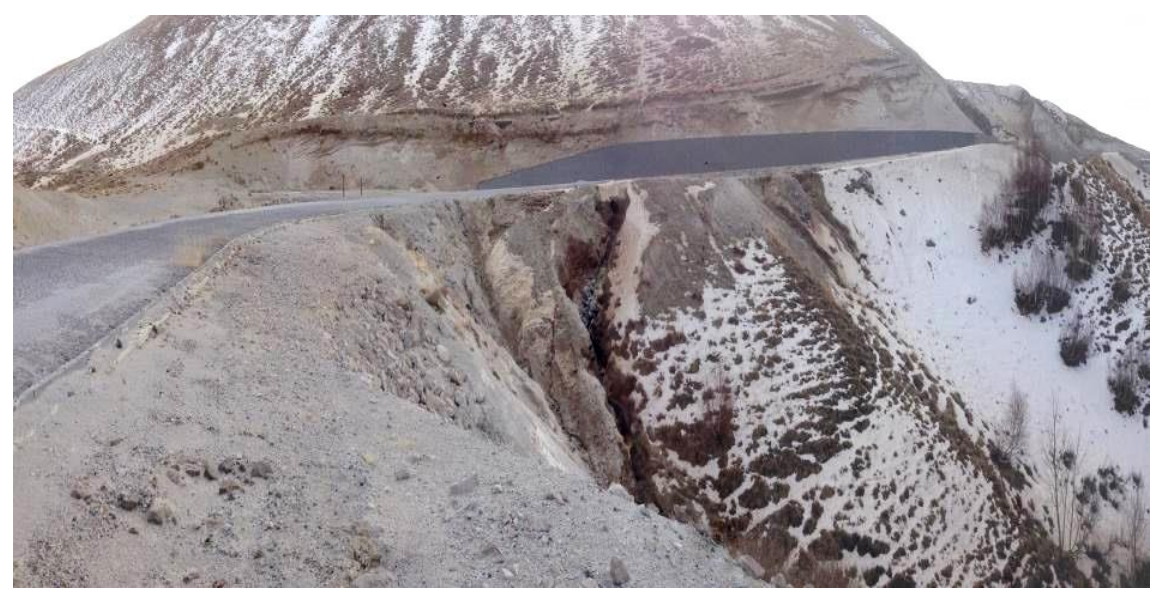

Figure 5. An Image Of The Flows And Slippages Observed In Pyroclastic Rocks At The Entrance Of The Nemrut Caldera Natural Monument (2017)

EC, PH and constitutive analyses of the soil in Nemrut caldera were conducted. According to analysis results; $16.4 \%$ clay, $12.8 \%$ silt, $70.8 \%$ sand were identified, and the soil in the caldera is defined as loamy sand. The electrical conductivity of the soil was 88.1 micromhos/cm unsalted, PH values were identified as 7.85 mild alkalines (Alp et al., 2017). The separation of rocks has caused the formation of clay minerals, which is an important building substance of the soil, due to the characteristic of the rocks. Thus, the water retention capacity of the lesser lands is reduced, and the accumulation of organic matter becomes lower. Both cases affect the development of plants. For this reason, delicate plants can be damaged in plant cultivation.

\section{CONCLUSION AND RECOMMENDATIONS}

Although Tatvan and its environs are the regions where the effects of the terrestrial climate are felt, the vegetation is more powerful and diverse, due to the high amount of moisture and direct solar radiation in the summer in the vicinity of the Crater Lake. In the region, the plant formation is developed depending on the annual dispersion of the precipitation and temperature conditions. The region has a plant presence rich in wood, bush and steppe crops.

Steppe crops often survive in the autumn and winter period and can sustain their presence until the period where drought begins. The presence of tree species in and around Crater Lake can be considered as an indication of the forest ruins of the region.

In the past, the region was covered with forests; It is seen that the forests are destroyed due to the population increase of the region, so their properties were disappeared. Such fields must be protected because they are an important indicators for our biological diversity.

With the increase in the income levels of the society, the visit to the field is increasing day by day. Increasing visits lead to problems such as the deterioration of the natural habitat of the area, the reduction of biodiversity and the lack of sustainability. When the existing field is examined, many misapplications and topics that need to be corrected have been identified. These can be collected in the headings "the flows caused by erosion" and "the flows caused by newly opened roads". 
Factors such as increased biotic repression and anthropogenic effect in the region cause erosion to be aggravating. The life of existing plants is also compromised when the soil structure changes in erosion areas. To prevent rapidly ongoing erosion, firstly it is necessary to preserve the vegetation in the area. The severity of erosion is increasing due to the effects of global climate change. To reduce the impact of erosion and to renew the area itself, the protection action plan must be created and enforced (Akman, 1990).

Astragalus sp., and J. communis subsp. nana species, which have developed all over the region and whose root system is well-developed, provide resistance to erosion. The surplus of plants belonging to the genus Poaceae, some of which reproduce with seed, stolon, burl or rhizome, is extremely important in the region for the prevention of erosion.

First of all, geotechnical design projects have to be created to prevent the slippage caused by the transportation road. To create geotechnical design projects, geotechnical parameters of the slippage surface must be produced. As a result of observational evaluations, it is necessary to perform drilling and geophysical studies starting from the entrance of Nemrut Crater for geotechnical purposes and to determine the thickness and physical properties of this loosefeatured unit in the upper layer. To form geotechnical bearing structures (retainer, bored pile, etc.), it is necessary first to make a $1 / 1000$ or 1/2000 scale map acquisition in the vicinity of the study area and then to determine the geological surface map, drilling locations and geophysical points on this map (Alp et al., 2017).

In the second stage, a permanent and sustainable landscape planning study should be carried out in the field, and especially the plant design project should be carefully planned within the scope of this study. Plant composition and application studies are different in each application area. One of the most important of these areas is the road between Tatvan-Nemrut Caldera Nature Monument which is the subject of the study and which requires revision as a result of its deteriorations. Highway landscape arrangements and planting studies should be done by persons who are specialized in related fields. On the other hand, coordinated studies should be conducted with the landscape architecture discipline while determining the route in the roadway. In this regard, a joint group should be formed with civil engineers, road construction experts, agricultural experts, and landscape architects. In particular, the Environmental Impact Assessment Report must be integrated into the planning system for the determination of the problems that may arise after the implementation and for the sustainability of the ecological balance.

In this study, besides the methods and materials that should be used, the considerations and recommendations for botanical applications are involved.

In the scope of landscaping studies, some important issues should be considered when selecting plant species. These;

-Natural plant species should be selected when selecting types of plant. The selected species must be determined from the species that prevent erosion and prevent soil erosion by means of plant root development and allow the surface to become firmer.

- Foreign species should not be used in the cultivation studies.

- Cultivation studies should be appropriate to the general character of the landscape of the environment through which the road route passes. This is very important in terms of the relationship and suitability between the road and environmental landscape. (Yeler, 2017). 
- For preventing the slippage in route through which the road passes, the current vegetation needs to be preserved and completed with planting. Especially if there are endemic, rare or endangered species, it should be given a further emphasis on their determination and preservation (Hocagil et al., 2012).

-The plantings to be made on the roads for whatever purpose (to attract attention to a specific point, to clarify some geomorphological properties of the terrain, to create a frame for beautiful appearances, etc.) must carry an aesthetic quality. (Akdoğan, 1967).

- In the selection of wood and bush species, the demands of land and environment are taken into consideration along with the petal shapes and beauties. Also, if the mixed use of tree species is supported by lower layer bushes, these plant groups and roadside planting become very interesting, and a much stronger relationship is established with environmental landscaping. (Seçkin, 1986).

- The size of the planting to be made (plant numbers in the groups to be created, planting intervals, etc.) must conform to the speed of the project. Plant numbers in the groups to be created should be kept larger, should be used in a large number of each type. However, groups and plant numbers can be kept less where people could pay more attention to detail, such as resting areas (Özgüç, 1999).

-In landscaping studies, a certain proportion of organic matter supplementation can be proposed to make the soil surface healthier and suitable for planting.

- Terracing, which purposes the prevention of wear of slope surfaces, should not be made. The terracing would disrupt the morphology of the terrain and damage the visual landscape quality of the area.

-Local seeds should be used in the sodding of the sloped surfaces with the method of hydroseeding, sloped surfaces must be laid with stone, plastered with spray mortar.

\section{REFERENCES}

Akdogan, G. (1967). Ankara-İstanbul Karayolu Güzergahının Peyzaj Özelliklerinin Etüdü İle Peyzaj Planlaması Yönünden Ele Alınması Gereken Problemler ve Tanzim Esasları. K. G. M. Yay. No: 158, İş Matbaacılık ve Ticaret. Ankara.

Akman, Y. (1990). İklim ve Biyoiklim. Palme Yayınları Mühendislik Serisi No: 103, Ankara. 304s.

Alp, Ş., Tapan, M., Özvan, A., Özdemir, Y., ve Akkaya, İ. (2017). Yayınlanmamış Bilirkişilik Raporu. Van.

Altinçekiç, S., ve Altinçekiç, H.. (2001). Karayolları Peyzaj Düzenleme Çalışmalarında Bitkilendirme Esasları. İstanbul Üniversitesi Orman Fakültesi Dergisi, Seri: B, 49-4, İstanbul.

Hocagil, M.M., Aydın, A., ve Yeler, O. (2012). Süs bitkileri sektörü yatırım el kitabı, Mersin, İklim Verisi (2018). https://tr.climate-data.org. Tatvan İli İklim Bilgisi Verileri.

Köseoolu, M.. (1980). Ege Bölgesinde Sosyo-Ekonomik Bakımdan Önemli Karayollarının Peyzaj Planlaması Üzerine Araştırmalar. E. Ü. Ziraat Fak. Yay. No:378, E.Ü.Ziraat Fak. Ofset Ünitesi, Bornova.

Özçelik H. (2016). Endemik Ranunculus poluninii ve Ranunculus crateris (Ranunculaceae) Populasyonları Üzerinde Taksonomik ve Ekolojik Araştırmalar SDU Journal of Science (E-Journal), 11 (1): 1-41 
Özgüç. İ.M. (1999). TEM Hadımköy Kınalı Arası Peyzaj Planlaması Üzerinde Görsel Araştırmalar. İ. Ü. Fen Bilimleri Enstitüsü. Yayınlanmamış Doktora Tezi, İstanbul.

Seçkin, Ö.B. (1986). Karayolu ve Peyzaj1. Ístanbul Üniversitesi Orman Fakültesi Dergisi, Seri: B, 36-4, İstanbul.

Seçkin. Ö.B. (1997). Peyzaj Yapıları ll. Fakülte Yayın No: 447, Üniversite Yayın No: 4029, ISBN: 975-404-464-3. İ.Ü. Basımevi ve Film Merkezi, İstanbul.

Selimoglu, B. (1994). Ülkemiz Otoyollarında Çevre Düzenleme İlkelerinin Belirlenmesi Üzerine Bir Araştırma. A.Ü. Fen Bilimleri Enstitüsü, Ankara.

Tatli, A. (1982). Nemrut Dağı'nın Bitki Sosyolojisi ve Bitki Ekolojisi Yönünden İncelenmesi, Atatürk Üniversitesi Fen Fakültesi Dergisi 1(1): 537-549.

Yeler, O. (2017). İtalya ve Hollanda Süs Bitkileri Sektörünün Üretim Yapıs1, Pazarlama ve Organizasyon Modeli Açısından İncelenmesi. Kilis 7 Aralık Üniversitesi Fen ve Mühendislik Dergisi, 1 (1): 7-14. 